\title{
Short-term effects of NPH insulin, insulin detemir, and insulin glargine on the GH-IGF1-IGFBP axis in patients with type 1 diabetes
}

\author{
Zhulin Ma ${ }^{1,2}$, Jens Sandahl Christiansen ${ }^{2}$, Torben Laursen ${ }^{3}$, Torsten Lauritzen ${ }^{4}$ and \\ Jan Frystyk ${ }^{1,2}$ \\ ${ }^{1}$ Medical Research Laboratory, Department of Clinical Medicine, Faculty of Health, Aarhus University, Nørrebrogade \\ 44, DK-8000 Aarhus C, Denmark, '2Department of Endocrinology and Internal Medicine, Aarhus University Hospital, \\ Nørrebrogade, DK-8000 Aarhus C, Denmark, ${ }^{3}$ Department of Biomedicine - Pharmacology, Faculty of Health, \\ Aarhus University, DK-8000 Aarhus C, Denmark and ${ }^{4}$ Section of General Practice, Department of Public Health, \\ Faculty of Health, Aarhus University, DK-8000 Aarhus C, Denmark
}

\author{
Correspondence \\ should be addressed \\ to Z Ma \\ Email \\ zhulin.ma@clin.au.dk
}

\begin{abstract}
Objective: Insulin regulates the GH-IGF1 axis. Insulin analogs differ from human insulin in receptor affinity and possibly liver accessibility. Therefore, we compared the GH-IGF1 axis response with human NPH insulin, insulin detemir, and insulin glargine in patients with type 1 diabetes (T1D).

Methods: A total of 17 patients (seven were women) with T1D (age of 42 (24-63) years (mean and range), BMI of 24.7 (19.5-28.3) kg/m², HbA1c of $7.2(6.3-8.0) \%(55(45-64) \mathrm{mmol} / \mathrm{mol})$, T1D duration of 26 (8-45) years) were studied using a randomized, three-period crossover design. Patients received s.c. injections of equal, individual doses of NPH, detemir, and glargine at $1800 \mathrm{~h}$. Plasma glucose, serum total IGF1, bioactive IGF, IGF-binding protein (IGFBPs), and GH were measured hourly for $14 \mathrm{~h}$ post-injection.

Results: When compared with the area under the curve (AUC) following NPH and glargine, detemir resulted in the lowest 6-14 h AUC (mean and range) of IGFBP1 (1518 (1280-1800)) vs 1621 (1367-1922) vs $1020(860-1210) \mu \mathrm{g} / \mathrm{l} \times \mathrm{h})$ and GH (17.1 (14.1-20.6) vs $15.4(12.7-18.6)$ vs $10.2(8.5-12.3) \mu \mathrm{g} / \mathrm{l} \times \mathrm{h})$, but in the highest AUC of bioactive IGF (3.8 (3.5-4.2) vs 3.7 (3.4-4.0) vs $4.4(4.1-4.8) \mu \mathrm{g} / \mathrm{l} \times \mathrm{h})($ all $P<0.01)$. These differences were unrelated to plasma glucose. By contrast, profiles of total IGF1, IGFBP2, and IGFBP3 were comparable.

Conclusions: Independent of plasma glucose, a single dose of detemir caused larger suppression in serum IGFBP1 than NPH and glargine, whereas bioactive IGF was higher, thereby explaining the lower GH levels. Thus, detemir appears to be more liver specific than NPH insulin and glargine.
\end{abstract}

\section{Introduction}

The insulin analogs glargine and detemir represent recent treatment alternatives resulting in flatter blood glucose profiles, prolonged duration of action, and less intraindividual day-to-day variation than human NPH insulin $(1,2,3)$. Insulin glargine differs from human insulin due to the replacement of glycine for asparagine at position A21
European Journal of

Endocrinology

(2014) 171, 471-479 and addition of two arginine molecules at position B30 (4). As a consequence of these modifications, glargine forms micro-precipitates in the subcutaneous tissue, wherefrom it is slowly released into the bloodstream. The principle of insulin detemir is quite different as it is based on the addition of a fatty acid (myristic acid) bound to lysine at 
position B29 (5). In contrast to glargine, detemir is absorbed rapidly after s.c. injection. However, as the fatty acid residue associates with high affinity with free fatty acid-binding sites on albumin, more than $98 \%$ of detemir circulates bound, albeit reversible, to albumin (6). Slow release from albumin as well as strong self-association of detemir leads to its prolonged hypoglycemic action and reduced variability.

Abnormalities in the growth hormone-insulin-like growth factor 1-insulin-like growth factor-binding protein (GH-IGF1-IGFBP) axis have consistently been reported in patients with type 1 diabetes (T1D). These abnormalities are consequences of portal insulinopenia and include $\mathrm{GH}$ hypersecretion, secondary to low circulating levels of IGF1 and elevated levels of IGFBP1 $(7,8,9)$. Although these abnormalities to a certain extent reflect the glycemic control (10), they are likely to be metabolically unfavorable per se. GH exerts insulin-antagonizing effects whereas IGF1 serves as an insulin sensitizer $(11,12)$. Tight glycemic control appears, however, to be unable to fully normalize the changes of the GH-IGF1-IGFBP axis (8). This may be explained by the inability to normalize portal insulin levels following s.c. insulin administration (13).

Owing to its association with albumin, the transcapillary transport of detemir is delayed in adipose tissue and skeletal muscle, whereas both free and albumin-bound detemir can freely access the hepatocytes through the open sinusoids in the liver. This may explain that detemir has a greater activity in the liver than in peripheral tissues when compared with NPH insulin $(14,15)$.

Based on the different modes of action of detemir (circulating depot) and glargine (s.c. depot), and the observation that detemir appears to possess an increased liver specificity, we hypothesized that detemir exerted a greater impact than glargine on the circulating IGF system, which primarily originates from the liver. In order to test this hypothesis, we performed a randomized crossover head-to-head comparison of detemir and glargine in patients with long-lasting T1D, using human NPH insulin as the control.

\section{Subjects and methods}

This was an open-label, randomized, three-period crossover study (www.ClinicalTrials.gov identification no. NCT01461616). The study protocol was approved by the local ethics committee and the Danish Medical Agency. The study was carried out according to the Declaration of Helsinki and the principles of Good Clinical Practice.
Written informed consent was obtained from all participants before any study procedures.

\section{Subjects}

Eligible patients were men and women who were $\geq 18$ years of age, diagnosed with T1D according to the WHO criteria 1999 (16) for at least 6 years, treated with continuous s.c. insulin infusion (CSII) for $\geq 6$ months at the time of inclusion, whose total daily insulin dose was $0.4-1.4$ units $/ \mathrm{kg}$, and having an HbA1c of $6-9 \%$ (42-75 $\mathrm{mmol} / \mathrm{mol}$ ) and a BMI of $18.5-28 \mathrm{~kg} / \mathrm{m}^{2}$. The use of CSII by patients ensured that none of the included participants had recently been exposed to long-lasting insulin preparations when they entered the study. The exclusion criteria included patients with allergy to investigational insulin, recurrent major hypoglycemia, acute myocardial infarction for $<12$ months or severe heart insufficiency, and impaired renal or hepatic function. Pregnant or breast-feeding women were also excluded.

\section{Procedures}

Following screening, eligible patients were assigned to a randomized treatment sequence with NPH insulin, insulin detemir, and insulin glargine on three separated profile days (1-6 weeks apart). On the profile days, patients reported to the Clinical Research Unit at noon, where a standardized meal was served. The standardized meal contained $3360 \mathrm{~kJ}$ and was composed of a fixed individual content of fat, carbohydrate, and protein, being prepared by our dieticians. The same type of meal was served on each of the three profile days. Before the standardized meal, bolus insulin was administered using the patient's insulin pump and the dose was adjusted according to the individual need. After the standardized meal, subjects remained fasted, apart from tap water until $0800 \mathrm{~h}$ next morning. At 1500 h, two i.v. cannulae were inserted into the peripheral veins, one for glucose and insulin infusion and the other for blood sampling. Meanwhile, patients were instructed to suspend their CSII pump. From 1500 to 1800 h, 5\% glucose and human insulin (Actrapid, Novo Nordisk, Bagsvaerd, Denmark) were infused to maintain blood glucose levels between 5 and $8 \mathrm{mM}$. The infusion rates were adjusted according to a predefined algorithm and blood glucose measurement every $30 \mathrm{~min}$. At $1800 \mathrm{~h}$, immediately after baseline blood sampling, an individual dose of either NPH insulin (Insulatard, Novo Nordisk A/S, $100 \mathrm{IU} / \mathrm{ml}$ ), insulin detemir (Levemir, Novo Nordisk A/S, 
$100 \mathrm{U} / \mathrm{ml}$ ), or insulin glargine (Lantus, Sanofi-Aventis Deutschland $\mathrm{GmbH}$, Berlin, Germany, $100 \mathrm{U} / \mathrm{ml}$ ) was injected subcutaneously into a lifted skin fold in the thigh. Insulin dose was calculated based on the habitual basal insulin dose from 2000 to $0800 \mathrm{~h}$. Thus, each of the patients received an individually calculated dose of the three study insulins. The same number of units was administered in the same injection area.

From $1800 \mathrm{~h}$ till next morning at $0800 \mathrm{~h}$, hourly blood samples were drawn for determination of plasma glucose and serum concentrations of IGFBP1, IGFBP2, and GH. Total IGF1 and IGFBP3 were measured at 1800, 0000, 0400 , and $0800 \mathrm{~h}$, while bioactive IGF was measured at $1800,2100,0000,0400$, and $0800 \mathrm{~h}$.

Bedsides, blood glucose levels for safety monitoring were measured every $30 \mathrm{~min}$ from $1500 \mathrm{~h}$ until the end of the study visit using a commercially available plasma glucose meter (Ascensia Contour, Bayer). Patients were treated with an i.v. injection of $10 \%$ glucose if the blood glucose measurement was $<3.1 \mathrm{mM}$.

\section{Laboratory assessment}

Plasma glucose was measured by the Immobilized Enzyme Biosensor on the YSI 2300 STAT Plus Glucose and Lactate Analyzer (YSI Incorporated, Yellow Springs, OH, USA).

Total IGF1, IGFBP3, and GH levels were determined by validated commercial chemiluminescence immunoassays using the IDS-iSYS multi-discipline automated analyzer (Immunodiagnostic Systems Nordic SA, Copenhagen, Denmark) according to the manufacturer's protocol. Limits of detection for total IGF1, IGFBP3, and GH were $4.4,50$, and $0.015 \mu \mathrm{g} / \mathrm{l}$ respectively.

Bioactive IGF was determined by an IGF1 receptor (IGF1R) kinase receptor activation (KIRA) assay as described previously (17) with modifications (18). Briefly, this assay determines the ability of serum IGFs to activate (i.e. phosphorylate) the IGF1R in vitro, using a HEK 293 cell line stably transfected with the human IGF1R gene.
The pool of IGF1R accessible IGF is a composite entity composed of free and dissociable IGF1. IGF2 is also recognized, albeit with a cross-reactivity that is only $12 \%$ of that of IGF1, whereas human insulin exerts $<1 \%$ crossreactivity. On this basis, we have denoted this measurement as 'bioactive IGF'. The KIRA assay has a detection limit of $<0.08 \mu \mathrm{g} / \mathrm{l}$, and intra- and inter-assay $\mathrm{CV}$ values of $<7$ and $<15 \%$ respectively. IGFBP1 was determined by an in-house time-resolved immunofluorometric assay (TR-IFMA) (18). The intra-assay CV value of samples assayed in duplicates averaged $<5 \%$, and the inter-assay CV value of an internal control (IGFBP1 standard) and a control serum sample averaged 8.1 and $7.0 \%$ respectively. IGFBP2 was determined by a validated in-house TR-IFMA (19) with intra- and inter-assay CV values of $<5$ and $<12 \%$ respectively.

\section{Statistical analysis}

This study had an $80 \%$ power to detect an absolute difference of $10 \mu \mathrm{g} / \mathrm{l}$ between the minimal values of serum total IGF1 concentrations, suggesting that at least 16 patients were needed to complete the study. Data were tested for normal distribution by using the Kolmogorov-Smirnov test. Natural logarithmic transformation was performed to improve the distribution of raw data as appropriate. For further comparison of the study insulins, the 14-h experiential period was divided by midnight (0000). The areas under the concentrationtime (AUC) curves were calculated using the trapezoidal rule and stratified into the initial phase (1800-0000 h) and the late phase (0000-0800 h). Differences in assessment endpoints were examined by ANOVA with treatment as a fixed factor, patient as a random factor, and baseline concentration as a covariance if necessary. Analysis of time-related effects was performed using the repeated measures ANOVA. Linear regression analyses were performed when applicable. Statistical analyses were performed using IBM SPSS Statistics version 20.0

Table 1 Baseline concentrations. Results are expressed as mean (range).

\begin{tabular}{l} 
Parameters \\
\hline Plasma glucose $(\mathrm{mM})$ \\
Total IGF1 $(\mu \mathrm{g} / \mathrm{l})$ \\
Bioactive IGF $(\mu \mathrm{g} / \mathrm{l})$ \\
IGFBP1 $(\mu \mathrm{g} / \mathrm{l})$ \\
IGFBP2 $(\mu \mathrm{g} / \mathrm{l})$ \\
IGFBP3 $(\mathrm{mg} / \mathrm{l})$ \\
GH $(\mu \mathrm{g} / \mathrm{l})$
\end{tabular}

\begin{tabular}{c}
\hline NPH insulin \\
\hline $7.1(6.5-7.7)$ \\
$118(112-123)$ \\
$0.74(0.66-0.83)$ \\
$61(45-83)$ \\
$439(392-486)$ \\
$2.76(2.68-2.84)$ \\
$0.36(0.22-0.59)$ \\
\hline
\end{tabular}

\begin{tabular}{c}
\hline Insulin detemir \\
\hline $7.1(6.5-7.7)$ \\
$118(112-123)$ \\
$0.76(0.68-0.85)$ \\
$77(57-105)$ \\
$497(450-544)$ \\
$2.72(2.64-2.80)$ \\
$0.47(0.29-0.76)$ \\
\hline
\end{tabular}

\begin{tabular}{|c|c|}
\hline Insulin glargine & $\boldsymbol{P}$ \\
\hline $6.9(6.3-7.5)$ & NS \\
\hline $118(113-124)$ & NS \\
\hline $0.76(0.68-0.85)$ & NS \\
\hline $72(53-98)$ & NS \\
\hline 466 (419-514) & NS \\
\hline $2.83(2.75-2.92)$ & NS \\
\hline $0.49(0.30-0.79)$ & NS \\
\hline
\end{tabular}


(IBM Corp., Somers, NY, USA). A $P$ value of $<0.05$ was considered statistically significant.

\section{Results}

A total of 19 patients were screened and randomized in this study. One patient withdrew after one study visit due to personal reasons, and another patient has withdrawn due to lack of compliance. Data from these patients are not included. Thus, 17 patients (ten men and seven women) aged 42 (24-63) years (mean and range), with a BMI of 24.7 (19.5-28.3) kg/m², a duration of T1D of $26(8-45)$ years, and a present HbA1c of 7.2 (6.3-8.0) \% (55 (45-64) $\mathrm{mmol} / \mathrm{mol}$ ) underwent all the study visits. The individual injection doses were identical to the habitual basal insulin dose infused from 2000 to $0800 \mathrm{~h}$ and averaged 12 (6-21) units for all patients.

\section{Baseline concentrations}

At baseline, plasma glucose concentration and serum concentrations of total IGF1, bioactive IGF, IGFBP1, IGFBP2, IGFBP3, and GH were comparable among the three study visits (Table 1).

\section{Pharmacodynamics}

The mean plasma glucose profiles are shown in Fig. 1A. $\mathrm{NPH}$ insulin, insulin detemir, and insulin glargine exhibited well-distinguished glucose profiles. Pharmacodynamic properties were similar for NPH insulin and insulin detemir in terms of maximum concentrations (Cmax) and AUCs of plasma glucose during the 14-h experiential period. After the injection of insulin glargine, plasma glucose slowly increased and reached a significantly higher Cmax when compared with insulin detemir (Table 2). Overall, insulin glargine resulted in significantly larger AUCs of plasma glucose than NPH and detemir insulins (all $P$ values $<0.05$ ).

\section{Hypoglycemia}

Two patients experienced three minor hypoglycemic episodes after the injection of study insulins. One patient had one episode with NPH insulin at $2.5 \mathrm{~h}$ after injection, the other patient experienced hypoglycemia with both insulin detemir at $6.5 \mathrm{~h}$ and insulin glargine at $4 \mathrm{~h}$ after injection. These events were treated with infusion of $10 \%$ glucose until the plasma glucose was stabilized above $3.1 \mathrm{mM}$.
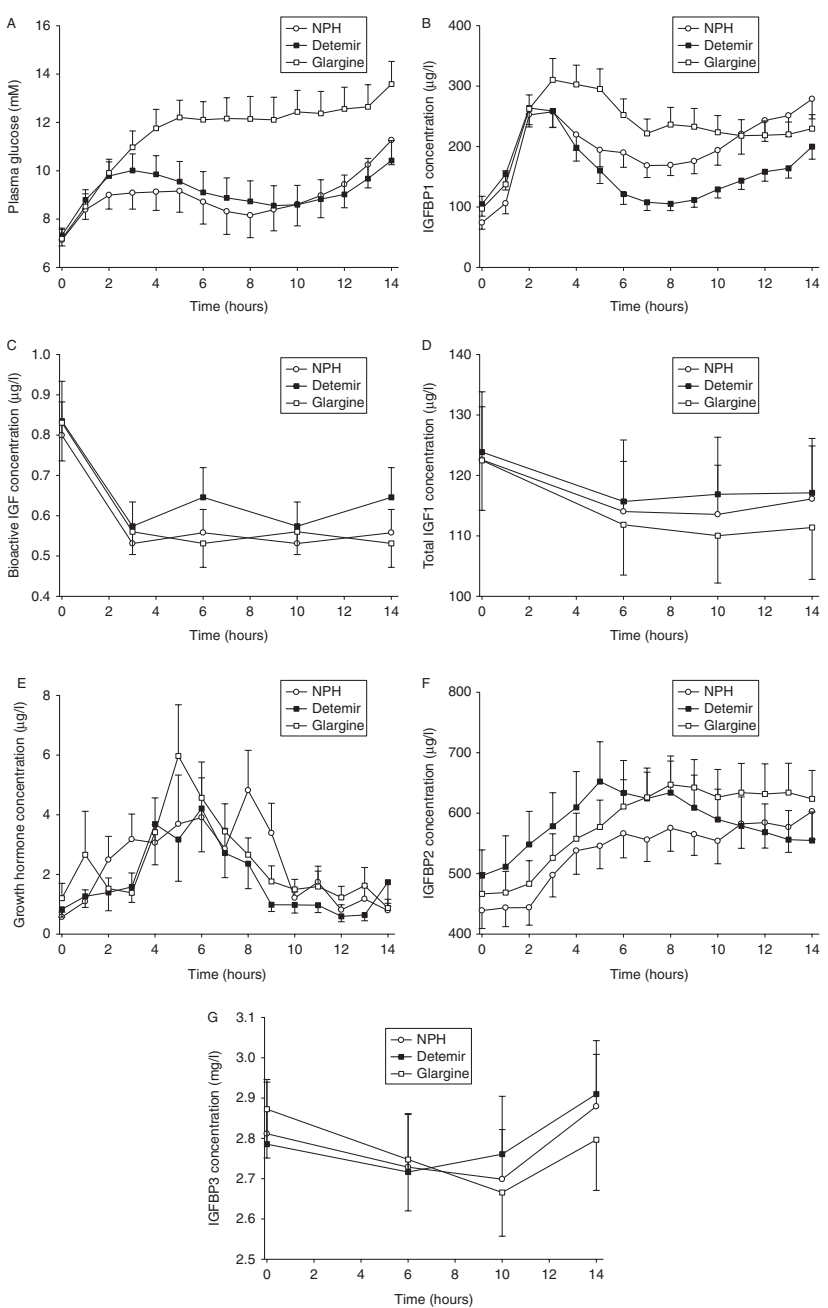

\section{Figure 1}

Plasma glucose (A), serum IGFBP1 (B), bioactive IGF (C), total IGF1 concentration (D), GH (E), IGFBP2 (F), and IGFBP3 levels (G) during $14 \mathrm{~h}$ treatment with NPH insulin (open circles), insulin detemir (black rectangles), and insulin glargine (open rectangles). Profiles are illustrated as mean \pm s.E.M.

Initial phase after insulin injection (the first $6 \mathrm{~h}, 1800-0000 \mathrm{~h}$ )

Following cessation of i.v. insulin infusion and s.c. injection of long-acting insulin preparations, a marked increase in serum IGFBP1 levels was observed during the initial $3 \mathrm{~h}$ of the study (Fig. 1B). On average, IGFBP1 reached peak values $2.9 \mathrm{~h}$ after NPH insulin injection, $2.7 \mathrm{~h}$ after insulin detemir, and $3.6 \mathrm{~h}$ after insulin glargine. The maximum concentrations of IGFBP1 were comparable in the three insulin groups. During the first $3 \mathrm{~h}$, IGFBP1 levels increased by 3.9-fold above baseline with 
NPH insulin, 3.0-fold with insulin detemir, and 3.8-fold with insulin glargine (all $P$ values $<0.05$ ). Hereafter, serum IGFBP1 was gradually suppressed. At $6 \mathrm{~h}$, levels were still higher than baseline for all insulin groups (all $P$ values $<0.05)$.

The initial increments in IGFBP1 were accompanied by reductions in levels of bioactive IGF (Fig. 1C). When compared with baseline, bioactive IGF levels decreased during the first $3 \mathrm{~h}$ by 33\% following NPH insulin, 31\% following insulin detemir, and 32\% following insulin glargine (all $P$ values <0.05). Correspondingly, serum total IGF1 levels revealed minor but significant reductions (Fig. 1D) with the treatment of NPH insulin, insulin detemir, and insulin glargine $(7,8$, and $10 \%$ respectively; all $P$ values $<0.05)$ during the $0-6 \mathrm{~h}$ period.

Serum GH concentrations gradually increased during this period (Fig. 1E). There was no significant difference in the time to reach the Cmax of GH after the three insulin injections (Table 2). However, patients had a significantly lower Cmax of GH with insulin detemir than with NPH insulin or insulin glargine (Table 2; $P<0.05$ ).

$\mathrm{NPH}$ insulin, insulin detemir, and insulin glargine yielded a similar $\mathrm{AUC}_{0-6}$ for total IGF1, bioactive IGF, IGFBP1, and GH during the first $6 \mathrm{~h}$ after the equal dose of injection (Table 2).

\section{Late phase (the last $8 \mathrm{~h}, 0000-0800 \mathrm{~h}$ )}

Slow increases in IGFBP1 levels were observed following $\mathrm{NPH}$ insulin and insulin detemir during the last 8-h period, whereas insulin glargine resulted in a rather stable IGFBP1 profile during that period (Fig. 1B). The mean IGFBP1 level was lower with insulin detemir than with the other insulin preparations (Table 2).

Insulin detemir differed from NPH insulin and insulin glargine in terms of $\mathrm{AUC}_{6-14}$ of IGFBP1, IGF bioactivity, and $\mathrm{GH}$ levels (all $P$ values $<0.05$ ). For these outcomes, the differences between two insulin analogs

Table 2 Results of plasma glucose and GH-IGF1-IGFBP parameters. The results are expressed as geometric mean (range) drawn from ANOVA. (a) $P<0.05$ vs NPH insulin, (b) $P<0.05$ vs insulin detemir, (c) $P<0.05$ vs insulin glargine.

\begin{tabular}{|c|c|c|c|c|}
\hline Parameters & NPH insulin (a) & Insulin detemir (b) & Insulin glargine (c) & $\boldsymbol{P}$ \\
\hline \multicolumn{5}{|l|}{ Plasma glucose } \\
\hline $\mathrm{Cmax}(\mathrm{mM})$ & $11.9(10.9-13.0)$ & $11.6(10.6-12.7)^{c}$ & $13.9(12.7-15.2)^{b}$ & 0.014 \\
\hline $\mathrm{AUC}_{0-6} \mathrm{~h}(\mathrm{mM} \times \mathrm{h})$ & $50(46-56)^{c}$ & $54(49-59)$ & $61(56-68)^{a}$ & 0.024 \\
\hline $\mathrm{AUC}_{6-14} \mathrm{~h}(\mathrm{mM} \times \mathrm{h})$ & $72(63-81)^{c}$ & $72(63-82)^{c}$ & $101(92-110)^{a, b}$ & 0.000 \\
\hline $\mathrm{AUC}_{0-14} \mathrm{~h}(\mathrm{mM} \times \mathrm{h})$ & $119(107-131)^{c}$ & $124(112-137)^{c}$ & $158(143-174)^{a, b}$ & 0.001 \\
\hline \multicolumn{5}{|l|}{ Total IGF1 } \\
\hline $\mathrm{Cmin}(\mu \mathrm{g} / \mathrm{l})$ & $106(103-109)$ & 106 (103-109) & $102(100-105)$ & NS \\
\hline $\mathrm{AUC}_{0-6} \mathrm{~h}(\mu \mathrm{g} \times \mathrm{h} / \mathrm{l})$ & $683(672-694)$ & $680(669-691)$ & $673(662-684)$ & NS \\
\hline $\mathrm{AUC}_{6-14} \mathrm{~h}(\mu \mathrm{g} \times \mathrm{h} / \mathrm{l})$ & $879(844-915)$ & $885(850-921)$ & $852(819-887)$ & NS \\
\hline $\mathrm{AUC}_{0-14} \mathrm{~h}(\mu \mathrm{g} \times \mathrm{h} / \mathrm{l})$ & $1562(1527-1600)$ & 1566 (1529-1603) & $1524(1489-1560)$ & NS \\
\hline \multicolumn{5}{|l|}{ Bioactive IGF } \\
\hline $\mathrm{AUC}_{0-6} \mathrm{~h}(\mu \mathrm{g} \times \mathrm{h} / \mathrm{l})$ & $3.4(3.2-3.6)$ & $3.6(3.4-3.8)$ & $3.4(3.2-3.6)$ & NS \\
\hline $\mathrm{AUC}_{6-14} \mathrm{~h}(\mu \mathrm{g} \times \mathrm{h} / \mathrm{l})$ & $3.8(3.5-4.2)^{b}$ & $4.4(4.1-4.8)^{a, c}$ & $3.7(3.4-4.0)^{\mathrm{b}}$ & 0.008 \\
\hline $\mathrm{AUC}_{0-14} \mathrm{~h}(\mu \mathrm{g} \times \mathrm{h} / \mathrm{l})$ & $7.3(6.9-7.8)$ & $8.1(7.6-8.6)^{c}$ & $7.1(6.7-7.6)^{b}$ & 0.018 \\
\hline \multicolumn{5}{|l|}{ IGFBP1 } \\
\hline $\mathrm{AUC}_{0-6} \mathrm{~h}(\mu \mathrm{g} \times \mathrm{h} / \mathrm{l})$ & 1126 (924-1370) & 1025 (843-1247) & $1322(1088-1606)$ & NS \\
\hline $\mathrm{AUC}_{6-14} \mathrm{~h}(\mu \mathrm{g} \times \mathrm{h} / \mathrm{l})$ & $1518(1280-1800)^{b}$ & $1020(860-1210)^{a, c}$ & $1621{(1367-1922)^{b}}^{b}$ & 0.001 \\
\hline $\mathrm{AUC}_{0-14} \mathrm{~h}(\mu \mathrm{g} \times \mathrm{h} / \mathrm{l})$ & $2722(2324-3187)$ & $2115(1807-2475)^{c}$ & $2960(2534-3462)^{b}$ & 0.011 \\
\hline \multicolumn{5}{|l|}{ IGFBP2 } \\
\hline $\mathrm{AUC}_{0-6} \mathrm{~h}(\mu \mathrm{g} \times \mathrm{h} / \mathrm{l})$ & 3157 (2975-3339) & 3273 (3091-3455) & 3158 (2980-3335) & NS \\
\hline $\mathrm{AUC}_{6-14} \mathrm{~h}(\mu \mathrm{g} \times \mathrm{h} / \mathrm{l})$ & $4578(4130-5027)$ & 4755 (4307-5203) & $5060(4611-5508)$ & NS \\
\hline $\mathrm{AUC}_{0-14} \mathrm{~h}(\mu \mathrm{g} \times \mathrm{h} / \mathrm{l})$ & 7902 (7395-8410) & 7855 (7347-8363) & 8222 (7727-8718) & NS \\
\hline \multicolumn{5}{|l|}{ IGFBP3 } \\
\hline $\mathrm{AUC}_{0-6} \mathrm{~h}(\mathrm{mg} \times \mathrm{h} / \mathrm{l})$ & $16.4(16.2-16.6)$ & $16.4(16.2-16.6)$ & $16.3(16.1-16.5)$ & NS \\
\hline $\mathrm{AUC}_{6-14} \mathrm{~h}(\mathrm{mg} \times \mathrm{h} / \mathrm{l})$ & $21.7(21.1-22.3)$ & $21.9(21.2-22.5)$ & $21.4(20.8-22.0)$ & NS \\
\hline $\mathrm{AUC}_{0-14} \mathrm{~h}(\mathrm{mg} \times \mathrm{h} / \mathrm{l})$ & $38.1(37.5-38.7)$ & $38.5(37.9-39.1)$ & $37.4(36.8-38.0)$ & NS \\
\hline \multicolumn{5}{|c|}{ (2. } \\
\hline $\mathrm{Cmax}(\mu \mathrm{g} / \mathrm{l})$ & $10.6(8.6-12.9)^{b}$ & $7.2(5.9-8.8)^{a, c}$ & $10.3(8.4-12.6)^{b}$ & 0.014 \\
\hline $\operatorname{Tmax}(\min )$ & $6.4(5.1-7.8)$ & $6.6(5.3-8.0)$ & $5.7(4.4-7.1)$ & NS \\
\hline $\mathrm{AUC}_{0-6} \mathrm{~h}(\mu \mathrm{g} \times \mathrm{h} / \mathrm{l})$ & $13.3(10.1-17.4)$ & $9.9(7.5-13.0)$ & $13.3(10.1-17.5)$ & NS \\
\hline $\mathrm{AUC}_{6-14} \mathrm{~h}(\mu \mathrm{g} \times \mathrm{h} / \mathrm{l})$ & $17.1(14.1-20.6)^{b}$ & $10.2(8.5-12.3)^{a, c}$ & $15.4(12.7-18.6)^{b}$ & 0.001 \\
\hline $\mathrm{AUC}_{0-14} \mathrm{~h}(\mu \mathrm{g} \times \mathrm{h} / \mathrm{l})$ & $31.7(27.8-36.2)^{b}$ & $22.2(19.5-25.3)^{a, c}$ & $31.3(27.5-35.6)^{b}$ & 0.000 \\
\hline
\end{tabular}


Table 3 Correlation coefficients from linear regression analysis in each treatment occasion.

\begin{tabular}{|c|c|c|c|c|}
\hline & $\begin{array}{c}\text { NPH } \\
\text { insulin }\end{array}$ & $\begin{array}{l}\text { Insulin } \\
\text { detemir }\end{array}$ & $\begin{array}{l}\text { Insulin } \\
\text { glargine }\end{array}$ & $\begin{array}{c}\text { All } \\
P \text { values }\end{array}$ \\
\hline IGFBP1 vs bioactive IGF & -0.30 & -0.32 & -0.30 & $<0.01$ \\
\hline $\begin{array}{l}\text { Total IGF1 vs } \\
\text { bioactive IGF }\end{array}$ & 0.31 & 0.30 & 0.26 & $<0.05$ \\
\hline Total IGF1 vs IGFBP2 & -0.47 & -0.56 & -0.70 & $<0.01$ \\
\hline Total IGF1 vs IGFBP3 & 0.76 & 0.83 & 0.80 & $<0.01$ \\
\hline
\end{tabular}

remained significant during the entire study period of $14 \mathrm{~h}$ (Table 2).

\section{IGFBP2 and IGFBP3 profiles}

The profiles of IGFBP2 and IGFBP3 demonstrated the same patterns, irrespective of the type of insulin (Fig. 1F and G). Unlike IGFBP1, the serum levels of IGFBP2 and IGFBP3 only showed minor changes after the insulin injections. NPH insulin, insulin detemir, and insulin glargine resulted in comparable AUCs of IGFBP2 and IGFBP3, respectively, during 0-6, 6-14, and 0-14 h (Table 2).

\section{Correlations between GH-IGF-IGFBP parameters}

Linear regression analysis was performed to examine the associations between the various peptides of the GHIGF-IGFBP system on each treatment occasion. For some peptides, the correlation coefficients were significant and similar for the different insulin treatments (Table 3). The analyses indicated that irrespective of the study insulin, there were significantly inverse correlations between the levels of IGFBP1 and bioactive IGF, whereas bioactive IGF concentrations as expected were positively correlated with total IGF1. In all treatment occasions, total IGF1 concentrations were inversely correlated with IGFBP2 levels, but positively correlated with IGFBP3 levels.

\section{Discussion}

The primary aim of this study was to investigate the responses of the GH-IGF-IGFBP axis to equal individual, single doses of NPH insulin, insulin detemir, and insulin glargine in patients with T1D during a 14-h overnight period. In the early phase, we observed similar, marked, and oppositely directed changes in the profiles of IGFBP1 and IGF bioactivity following injection of NPH insulin, insulin detemir, and insulin glargine. By contrast, during the last $8 \mathrm{~h}$ of study, insulin detemir resulted in different profiles of IGFBP1, bioactive IGF, and GH when compared with those obtained following NPH insulin and insulin glargine. Thus, insulin detemir treatment is associated with significantly lower IGFBP1 levels, a higher IGF bioactivity, and a greater suppression in GH levels than insulin glargine over the 14 -h period. By contrast, the three insulin preparations demonstrated similar effects on total IGF1, IGFBP2, and IGFBP3 profiles. Notably, the observed changes in the GH-IGF1-IGFBP axis appeared to be unrelated to changes in plasma glucose, as NPH insulin and insulin detemir showed similar effects on glucose control, while insulin glargine was accompanied by higher glucose levels.

This study included patients who were normally treated with rapid-acting insulin only, delivered by CSII (pump). This infusion was stopped $3 \mathrm{~h}$ before the start of the study, whereafter patients received a 3-h lasting i.v. glucose infusion containing short-acting insulin, until the long-acting insulin preparations were administered by s.c. injection. Using such a design, we ensured that our study solely described the effect of the long-acting insulin preparations on plasma glucose and the circulating $\mathrm{GH}-$ IGF1-IGFBP axis. On the other hand, as we focused exclusively on a highly selected group of patients with T1D, care has to be taken when trying to extrapolate our findings to patients treated with other insulin regimes.

Using the same individual doses of the three longacting insulin preparations, we expected comparable plasma glucose profiles as described previously (20), thereby enabling us to compare the activity of the various components of the GH-IGF axis during similar glycemic conditions. However, our findings failed to meet this assumption and evidently this is a limitation of our study. We observed clearly distinguishable glucose profiles reflecting the different pharmacokinetic profiles of NPH insulin, insulin detemir, and insulin glargine. Insulin detemir showed similar effects as NPH insulin on basal glycemic control, whereas insulin glargine resulted in the highest glucose Cmax and the largest AUC of plasma glucose among the three study insulins. The relatively slow release of subcutaneously injected insulin glargine into the circulation (3) is likely to account for this observation. Two previously published studies support our findings. Heise et al. compared the pharmacokinetic profile of a single dose of s.c. NPH insulin, insulin glargine, and insulin detemir by the glucose-infusion rate (GIR) during a euglycemic clamp technique in patients with T1D. The authors reported the GIR of the first $12 \mathrm{~h}$ to be 27 and 44\% higher for insulin detemir and NPH insulin, respectively, than that observed following insulin glargine 
(1). Similarly, Sørensen et al. (20) observed a 49\%, albeit statistically insignificant, higher GIR during the first $4 \mathrm{~h}$ following insulin detemir as compared with insulin glargine when investigating healthy, non-diabetic subjects. Thus, there is evidence supporting that following a single s.c. dose, insulin detemir has a faster onset of action than insulin glargine, despite their otherwise comparable long-term metabolic effects $(21,22)$.

Circulating IGFBP1 originates from the liver and its synthesis is primarily regulated by insulin, whereas glucose as also shown in this study plays a minor role (23). On this basis, serum IGFBP1 can be used as a circulating marker of the hepatic insulin exposure and sensitivity $(24,25)$. With the same doses, insulin detemir resulted in the lowest IGFBP1 levels among the three study insulins, thereby demonstrating that detemir more efficiently than NPH insulin and glargine is able to downregulate the hepatic production and secretion of IGFBP1. This observation fits with findings by others demonstrating that albumin-bound insulin detemir has a greater effect on the liver than on peripheral tissues (14). When comparing NPH insulin and glargine, the latter resulted in significantly higher plasma glucose levels, whereas levels of IGFBP1 did not differ between the two insulin preparations. From this, we conclude that the hepatic exposure to subcutaneously administered insulin cannot be deduced from the measurement of plasma glucose. Furthermore, based on serum IGFBP1 levels, our data suggest that insulin detemir is more liver specific than $\mathrm{NPH}$ insulin as well as glargine.

Our study demonstrated an inverse association between IGFBP1 and IGF bioactivity. By employing a highly specific cell-based IGF1R bioassay, we were able to determine in vitro the biologically active concentration of IGF1 and IGF2 (i.e. free and dissociable IGFs) being able to activate IGF1R $(17,26)$. Our results demonstrated that levels of IGFBP1 correlated inversely with levels of bioactive IGF during all insulin treatment occasions. This finding supports that IGFBP1 acts as a strong inhibitor of IGF bioactivity (27). During the first $3 \mathrm{~h}$, the marked increases in IGFBP1 levels were opposed by reductions in bioactive IGF. Furthermore, the significantly lower IGFBP1 AUC after insulin detemir injection was accompanied by the highest AUC of bioactive IGF among the three study insulins. The decreased circulating IGFBP1 is likely to result in a reduction in the total IGF-binding capacity, thereby increasing the fraction of bioactive IGF $(28,29)$. NPH insulin and insulin glargine had comparable effects on IGF bioactivity.
In this study, serum total IGF1 and IGFBP3 remained unchanged during our study and no differences in the AUCs between the three study insulins were detected. Thus, serum total IGF1 cannot explain the difference we observed with regard to serum GH. Therefore, we find it of interest that insulin detemir, which had the highest bioactive IGF concentration among the three study insulins, is associated with the lowest GH concentration in terms of Cmax and AUCs. On this basis, we suggest that the higher levels of bioactive IGF by feedback could be responsible for the lower overnight GH levels. This observation is consistent with the findings of Chen et al. (30), which demonstrated that the GH secretion during fasting appeared to be feedback regulated by free and bioactive IGF rather than total IGF1.

In contrast to IGFBP1, IGFBP2 and IGFBP3 displayed only small changes during the 14-h lasting experimental periods. No significant differences in IGFBP2 or IGFBP3 outcomes could be detected among the three insulin preparations. We found strong positive correlations between IGFBP3 and total IGF1, a finding in accordance with the role of IGFBP3 as the primary binding protein for IGF1 (31). The regulators of serum IGFBP2 remain to be established. However, elevated IGFBP2 levels have been reported in T1D, even in patients with very good glycemic control (7), and this indicates that the portal insulin level plays a certain role in IGFBP2 regulation. Our data also demonstrated an inverse correlation between IGFBP2 and total IGF1, which supports the role of IGFBP2 as a key factor in the crosstalk between insulin and the IGF system (32).

The clinical implications of our findings remain to be determined, and it also needs to be investigated whether the observed differences between detemir and glargine persist during long-term treatment. However, we believe that the combination of a reduced GH secretion and an increased IGF1R-mediated action may have beneficial metabolic effects in patients with T1D. This view is based on the well-known insulin-antagonizing actions of GH and the insulin-sensitizing actions of IGF1 $(11,12)$. Accordingly, the observed changes are likely to stimulate overall insulin sensitivity. Furthermore, it is important to acknowledge that bioactive IGF remained within the physiological range (26), thereby making it unlikely that this may cause unwanted long-term IGF1R-mediated side effects. Finally, it could be hypothesized that it is beneficial to suppress the augmented secretion of GH in T1D, as an elevated GH secretion has been linked to the development of late-stage diabetic complications such as retinopathy (33) and nephropathy (34). 
In conclusion, this study demonstrated that, with the same doses, insulin detemir resulted in a more marked suppression of IGFBP1 than NPH insulin and insulin glargine under the 14-h experimental condition. The lower IGFBP1 concentration obtained after insulin detemir injection exerted influences on the levels of bioactive IGF and GH, but not on the total IGF1. Owing to the pharmacokinetic characteristics of insulin detemir, this analog appears to have the potential to improve the secondary GH hypersecretion caused by perturbation of GH-IGF-IGFBP axis in patients with T1D. However, this hypothesis requires further attention and its clinical relevance also needs to be determined.

\section{Declaration of interest}

J S Christiansen is the member of speaker's bureau and Advisory Boards and recipient of unrestricted research grants from Novo Nordisk. T Laursen has received unrestricted grants for the ADDITION study (screening and intensive treatment of type 2 diabetes in primary care) from public foundations and the Medical Industry: Novo Nordisk A/S, Novo Nordisk Scandinavia AB, ASTRA Denmark, Pfizer Denmark, GlaxoSmithKline Pharma Denmark, SERVIER Denmark A/S and HemoCue Denmark A/S. $T$ Laursen has held three lectures for the medical industry within the past 2 years. T Laursen holds shares in Novo Nordisk. The other authors have nothing to disclose.

Funding

$\mathrm{Z} \mathrm{Ma}$ is the recipient of unrestricted grants for research from Novo Nordisk.

\section{Author contribution statement}

Z Ma conducted the clinical study, analyzed data and wrote the manuscript. J S Christiansen, T Laursen and T Lauritzen contributed to the discussion and reviewed/edited the manuscript. J Frystyk contributed to interpretation of the results and wrote the manuscript.

\section{Acknowledgements}

The authors would like to thank our research nurses Karen Lund and Ulla Sigsgaard for their efforts in dealing with practical issues. The skilled technical assistances from Kirsten Nyborg Rasmussen, Susanne Sorensen, and Lone Kvist are also highly appreciated.

\section{References}

1 Heise T, Nosek L, Ronn BB, Endahl L, Heinemann L, Kapitza C \& Draeger E. Lower within-subject variability of insulin detemir in comparison to NPH insulin and insulin glargine in people with type 1 diabetes. Diabetes 200453 1614-1620. (doi:10.2337/diabetes.53. 6.1614)

2 Heinemann L, Sinha K, Weyer C, Loftager M, Hirschberger S \& Heise T. Time-action profile of the soluble, fatty acid acylated, long-acting insulin analogue NN304. Diabetic Medicine 199916 332-338. (doi:10.1046/j.1464-5491.1999.00081.x)
3 Hirsch IB. Insulin analogues. New England Journal of Medicine 2005352 174-183. (doi:10.1056/NEJMra040832)

4 Campbell RK, White JR, Levien T \& Baker D. Insulin glargine. Clinical Therapeutics 200123 1938-1957. (doi:10.1016/S0149-2918 (01)80148-X)

5 Markussen J, Havelund S, Kurtzhals P, Andersen AS, Halstrom J, Hasselager E, Larsen UD, Ribel U, Schaffer L, Vad K et al. Soluble, fatty acid acylated insulins bind to albumin and show protracted action in pigs. Diabetologia 199639 281-288. (doi:10.1007/BF00418343)

6 Owens DR \& Bolli GB. Beyond the era of NPH insulin - long-acting insulin analogs: chemistry, comparative pharmacology, and clinical application. Diabetes Technology \& Therapeutics 200810 333-349. (doi:10.1089/dia.2008.0023)

7 Hedman CA, Frystyk J, Lindstrom T, Chen JW, Flyvbjerg A, Orskov H \& Arnqvist HJ. Residual $\beta$-cell function more than glycemic control determines abnormalities of the insulin-like growth factor system in type 1 diabetes. Journal of Clinical Endocrinology and Metabolism 200489 6305-6309. (doi:10.1210/jc.2004-0572)

8 Ekman B, Nystrom F \& Arnqvist HJ. Circulating IGF-I concentrations are low and not correlated to glycaemic control in adults with type 1 diabetes. European Journal of Endocrinology 2000143 505-510. (doi:10.1530/eje.0.1430505)

9 Bereket A, Lang CH \& Wilson TA. Alterations in the growth hormoneinsulin-like growth factor axis in insulin dependent diabetes mellitus. Hormone and Metabolic Research 199931 172-181. (doi:10.1055/ s-2007-978716)

10 Hanaire-Broutin H, Sallerin-Caute B, Poncet MF, Tauber M, Bastide R, Rosenfeld R \& Tauber JP. Insulin therapy and GH-IGF-I axis disorders in diabetes: impact of glycaemic control and hepatic insulinization. Diabetes \& Metabolism 199622 245-250.

11 Holt RI, Simpson HL \& Sonksen PH. The role of the growth hormoneinsulin-like growth factor axis in glucose homeostasis. Diabetic Medicine 200320 3-15. (doi:10.1046/j.1464-5491.2003.00827.x)

12 Clemmons DR. Modifying IGF1 activity: an approach to treat endocrine disorders, atherosclerosis and cancer. Nature Reviews. Drug Discovery 20076 821-833. (doi:10.1038/nrd2359)

13 Hanaire-Broutin H, Sallerin-Caute B, Poncet MF, Tauber M, Bastide R, Chale JJ, Rosenfeld R \& Tauber JP. Effect of intraperitoneal insulin delivery on growth hormone binding protein, insulin-like growth factor (IGF)-I, and IGF-binding protein-3 in IDDM. Diabetologia 1996 39 1498-1504. (doi:10.1007/s001250050604)

14 Hordern SV, Wright JE, Umpleby AM, Shojaee-Moradie F, Amiss J \& Russell-Jones DL. Comparison of the effects on glucose and lipid metabolism of equipotent doses of insulin detemir and NPH insulin with a 16-h euglycaemic clamp. Diabetologia 200548 420-426. (doi:10.1007/s00125-005-1670-1)

15 Smeeton F, Shojaee MF, Jones RH, Westergaard L, Haahr H, Umpleby AM \& Russell-Jones DL. Differential effects of insulin detemir and neutral protamine Hagedorn (NPH) insulin on hepatic glucose production and peripheral glucose uptake during hypoglycaemia in type 1 diabetes. Diabetologia 200952 2317-2323. (doi:10.1007/s00125 009-1487-4)

16 World Health Organization: Definition, Diagnosis and Classification of Diabetes Mellitus and its Complications: Report of a WHO Consultation. Part 1: Diagnosis and Classification of Diabetes Mellitus. Geneva, World Health Org 1999.

17 Chen JW, Ledet T, Orskov H, Jessen N, Lund S, Whittaker J, De MP, Larsen MB, Christiansen JS \& Frystyk J. A highly sensitive and specific assay for determination of IGF-I bioactivity in human serum. American Journal of Physiology. Endocrinology and Metabolism 2003284 E1149-E1155. (doi:10.1152/ajpendo.00410.2002)

18 Reinhard M, Frystyk J, Jespersen B, Bjerre M, Christiansen JS Flyvbjerg A \& Ivarsen P. Effect of hyperinsulinemia during hemodialysis on the insulin-like growth factor system and inflammatory biomarkers: a randomized open-label crossover study. BMC Nephrology 20131480. (doi:10.1186/1471-2369-14-80) 
19 Krassas GE, Pontikides N, Kaltsas T, Dumas A, Frystyk J, Chen JW \& Flyvbjerg A. Free and total insulin-like growth factor (IGF)-I, -II, and IGF binding protein-1, -2 , and -3 serum levels in patients with active thyroid eye disease. Journal of Clinical Endocrinology and Metabolism 200388 132-135. (doi:10.1210/jc.2002-021349)

20 Sørensen LP, Brock B, Mengel A, Rungby J, Moller N, Nielsen S, Volund A \& Schmitz O. Similarity of pharmacodynamic effects of a single injection of insulin glargine, insulin detemir and NPH insulin on glucose metabolism assessed by 24-h euglycaemic clamp studies in healthy humans. Diabetic Medicine 201027 830-837. (doi:10.1111/ j.1464-5491.2010.03026.x)

21 Heise T \& Pieber TR. Towards peakless, reproducible and long-acting insulins. An assessment of the basal analogues based on isoglycaemic clamp studies. Diabetes, Obesity \& Metabolism 20079 648-659. (doi:10.1111/j.1463-1326.2007.00756.x)

22 Swinnen SG, Simon AC, Holleman F, Hoekstra JB \& Devries JH. Insulin detemir versus insulin glargine for type 2 diabetes mellitus. Cochrane Database of Systematic Reviews 2011 CD006383. (doi:10.1002/ 14651858)

23 Fowelin J, Attvall S, von Schenck H, Smith U, Lager I \& Hall K. Regulation of insulin-like growth factor binding protein-1 (IGFBP-1) in insulin-dependent diabetes mellitus. Effects of hyperglycaemia and insulin. Acta Diabetologia 199431 183-186. (doi:10.1007/BF00571948)

24 Brismar K, Fernqvist-Forbes E, Wahren J \& Hall K. Effect of insulin on the hepatic production of insulin-like growth factor-binding protein-1 (IGFBP-1), IGFBP-3, and IGF-I in insulin-dependent diabetes. Journal of Clinical Endocrinology and Metabolism 199479 872-878. (doi:10.1210/ jcem.79.3.7521354)

25 Kotronen A, Lewitt M, Hall K, Brismar K \& Yki-Jarvinen H. Insulin-like growth factor binding protein 1 as a novel specific marker of hepatic insulin sensitivity. Journal of Clinical Endocrinology and Metabolism 2008 93 4867-4872. (doi:10.1210/jc.2008-1245)

26 Frystyk J. Quantification of the GH/IGF-axis components: lessons from human studies. Domestic Animal Endocrinology 201143 186-197. (doi:10.1016/j.domaniend.2011.11.005)
27 Frystyk J, Hojlund K, Rasmussen KN, Jorgensen SP, WildnerChristensen M \& Orskov H. Development and clinical evaluation of a novel immunoassay for the binary complex of IGF-I and IGF-binding protein-1 in human serum. Journal of Clinical Endocrinology and Metabolism 200287 260-266. (doi:10.1210/jcem.87.1.8147)

28 Chen JW, Nielsen MF, Caumo A, Vilstrup H, Christiansen JS \& Frystyk J. Changes in bioactive IGF-I and IGF-binding protein-1 during an oral glucose tolerance test in patients with liver cirrhosis. European Journal of Endocrinology 2006155 285-292. (doi:10.1530/eje. 1.02218)

29 Clemmons DR. Modifying IGF1 activity: an approach to treat endocrine disorders, atherosclerosis and cancer. Nature Reviews. Drug Discovery 20076 821-833. (doi:10.1038/nrd2359)

30 Chen JW, Hojlund K, Beck-Nielsen H, Sandahl CJ, Orskov H \& Frystyk J. Free rather than total circulating insulin-like growth factor-I determines the feedback on growth hormone release in normal subjects. Journal of Clinical Endocrinology and Metabolism 200590 366-371. (doi:10.1210/jc.2004-0039)

31 Baxter RC. Insulin-like growth factor (IGF)-binding proteins: interactions with IGFs and intrinsic bioactivities. American Journal of Physiology. Endocrinology and Metabolism 2000278 E967-E976.

32 Arafat AM, Weickert MO, Frystyk J, Spranger J, Schofl C, Mohlig M \& Pfeiffer AF. The role of insulin-like growth factor (IGF) binding protein2 in the insulin-mediated decrease in IGF-I bioactivity. Journal of Clinical Endocrinology and Metabolism 200994 5093-5101. (doi:10.1210/ jc.2009-0875)

33 Frystyk J. The growth hormone hypothesis - revision. Hormone and Metabolic Research 200537 (Suppl 1) 44-48. (doi:10.1055/s-2005861362)

34 Cingel-Ristic V, Flyvbjerg A \& Drop SL. The physiological and pathophysiological roles of the GH/IGF-axis in the kidney: lessons from experimental rodent models. Growth Hormone \& IGF Research 200414 418-430. (doi:10.1016/j.ghir.2004.06.003)

Received 31 March 2014

Revised version received 29 June 2014

Accepted 8 July 2014 